Бандура І. І., Бісько Н. А., Кулик А. С., Цизь О. М., Чаусов С. В., Василенко О. Ю., Гончаров С. М.

УДК 635.82

ТЕХНОЛОГІЧНІ ЗАСАДИ ВПРОВАДЖЕННЯ ОПЕНЬКА ЗИМОВОГО

FLAMMULINA VELUTIPES (CURTIS) SINGER

У ПРОМИСЛОВУ КУЛЬТУРУ

I. І. БАНДУРА, кандидат сільськогосподарських наук, доцент https://orcid.org/0000-0001-7835-3293

Таврійський державний агротехнологічний університет ім. Дмитра Моторного

Н. А. БІСЬКО, доктор біологічних наук, професор https://orcid.org/0000-0003-1894-0896

Інститут ботаніки ім. М. Г. Холодного НАН Украӥни

А. С. КУЛИК, кандидат технічних наук, доцент https://orcid.org/0000-0001-5403-3084

Таврійський державний агротехнологічний університет ім. Дмитра Моторного

О. М. ЦИЗь, кандидат сільськогосподарських наук, доцент https://orcid.org/0000-0001-7174-7011

Національний університет біоресурсів і природокористування Украӥни

С. В. ЧАУСОВ, кандидат технічних наук, доцент https://orcid.org/0000-0003-3811-9077

Таврійський державний агротехнологічний університет ім. Дмитра Моторного

О. Ю. ВАСИЛЕНКО, СФГ "Жовтневе" https://orcid.org/0000-0002-2449-6456

С. М. ГОНЧАРОВ, ФОП Гончаров С. М. https://orcid.org/0000-0001-6733-701X

E-mail: irabandura@gmail.com

https://doi.org/10.31548/dopovidi2020.05.004

Анотація. Опеньок зимовий - енокітаке або енокі один з найпоширеніших на планеті грибів, що культивуються штучно. В Украйні цей гриб з успіхом вирощується в умовах малооб'ємних виробництв, але не впроваджений в промислову культуру. Метою роботи було визначення ефективних технологічних засад виробництва опенька зимового з використанням місиевих залишків рослинної сировини. Скринінгом 10 штамів $з$ Колекиії культур шапинкових грибів ІВК визначено три штами 2038 (біла раса), 2039 та 2337 (жовта раса), що є перспективними для інтродукиії в індустріальні умови $і$ їх основні технічні характеристики: біологічна ефективність та тривалість циклу першої хвилі плодоношення. Загальний термін отримання плодових тіл фламуліни складав у середньому 40 діб. Апробовано рецептури формул субстратів, які забезпечують технологічність процесу їх виготовлення $i$ придатні для підвищення ефективності культивованих штамів. Знайдено технологічний інгредієнт субстратів - гранули з лушпиння соняшнику, що дозволяють прискорити прочес підготовки субстрату та забезпечують необхідну щцільність матеріалу. Виявлено, щьо біологічна ефективність штаму 
Бандура І. І., Бісько Н. А., Кулик А. С., Цизь О. М., Чаусов С. В., Василенко О. Ю., Гончаров С. М.

2039 опенька зимового, вирощеного у пакетах масою субстрату 1500 г була вищуою в 1,6 рази порівняно з варіантом культивування у пакетах масою 30002. Потрібно зазначити, щзо морфологічні особливості відібраних штамів за умов вирощування на місцевих сільськогосподарських відходах, а також вплив мікрокліматичних умов на їхню продуктивність, стійкість до захворювань потребують подальших досліджень.

Ключові слова: опеньок зимовий, Flammulina velutipes, скринінг, технологічні засади, біологічна еффективність, технологічний изилл, субстрати, біохімічний склад, функціональні речовини, інтродукція итамів

Актуальність. Опеньок гольчатий гриб» (Golden Needle зимовий Flammulina velutipes (Curtis) Mushroom) (рис. 1) не лише за Singer, один 3 п’яти найбільш відповідну форму плодових тіл та поширених у світі їстівних грибів, що культивуються штучно. В країнах Азії його називають «енокітаке» (скорочено «енокі») або «золотий

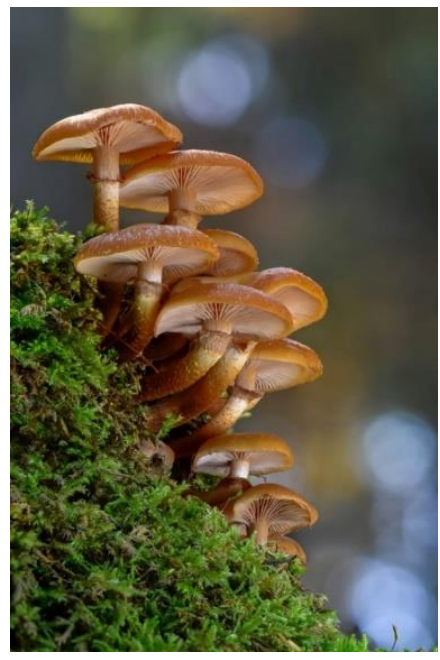

a) жовто-золотий відтінок шапинок, а й за високі смакові та поживні властивості [1].

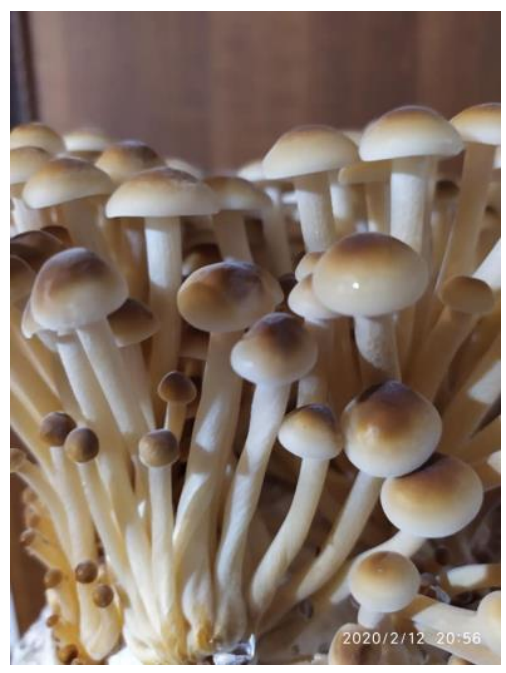

б)

Рис. 1. Опеньок зимовий (Flammulina velutipes): a) в природі (інтернетресурс); б) за умов інтенсивного культивування - штам 2337 (фото Гончарова С. М.)

Зростаючий інтерес світового промислового грибівництва до енокі підтверджується значним зростанням кількості наукових публікацій, які націлені на пошуки оптимальних рішень технологічних питань, пов'язаних 3 особливостями інтенсивного вирощування [2].
Цінні властивості фламуліни вже зробили їі відомою на ринках Свропи і США, але в Україні промислове виробництво цього гриба не започатковано. Вітчизняні вчені давно проаналізували таку можливість та запропонували основні шляхи отримання цінної грибної сировини [3-6]. У Колекцію культур 
Бандура І. І., Бісько Н. А., Кулик А. С., Цизь О. М., Чаусов С. В., Василенко О. Ю., Гончаров С. М.

шапинкових грибів IBK (2016) депоновано 42 штами Flammulina velutipes, виділених 3 природніх зразків та отриманих від дослідників інших країн [7]. Але головним стримуючим фактором $\epsilon$ відсутність технологій, що адаптовані до використання місцевих сільськогосподарських залишків, придатних для вирощування зимових опеньків, не вивчені особливості створення необхідних мікрокліматичних умов, тощо. Піонерами цього перспективного напряму вітчизняного грибівництва стали Василенко О. Ю., голова СФГ "Жовтневе" (м. Дніпро) та ФОП Гончаров С. М. (м. Дніпрорудне Запорізької області).

Аналіз останніх досліджень та публікацій. Морфологічні ознаки штамів опенька зимового за умов інтенсивного культивування кардинально відрізняються від дикорослих, які $\epsilon$ достатньо поширеними в лісах України 3 місцевими назвами - вербівка, лубинка зимова, фламуліна. У штучно вирощеного опенька ніжку витягують до 200 мм за рахунок спеціальних «комірців», оскільки відомо, що в основі ніжки опенька міститься велика кількість біологічно-активних полісахаридів, які мають протипухлинну дію [8]. 3 розвитком напряму функціонального харчування, науковий інтерес до цих грибів значно зростає: в плодових тілах фламуліни виявляють унікальний білок FIP-fve (fungal immunomodulatory protein), який стимулює активність периферійних лімфоцитів та пригнічує систему анафілактичних реакцій організму [9]. Вчені 3 Китаю запевняють, що екстракти та порошки 3 плодових тіл опенька містять дієтичні харчові волокна, полісахариди та мікостерол, які здатні до зниження рівня цукру, холестеролу та кров'яного тиску [10,11]. Японські дослідники виділили 3 екстрактів міцелію опенька та його культуральної рідини антиоксидантну амінокислоту - ерготионеїн, яка перешкоджає автоокисненню оксіміоглобіну та ліпідів, протидіє вільним радикалам [12].

Приємний смак, висока поживна цінність та достатньо проста технологія культивування забезпечили активне впровадження опенька зимового у промислову штучну культуру. Хоча перші роботи, присвячені вирощуванню фламуліни відносяться до початку минулого століття, пік наукового інтересу припадає на 60-90 роки [13]. Опеньок зимовий стає першим грибом, ріст якого вивчають у космосі в багаторазовій космічній лабораторії «Спейслеб» [14]. Виявилося, що невагомість загалом не впливає на морфогенез і ріст плодових тіл цього гриба, що розкриває перспективи його використання для функціонального харчування дослідників космічних просторів. 
Бандура І. І., Бісько Н. А., Кулик А. С., Цизь О. М., Чаусов С. В., Василенко О. Ю., Гончаров С. М.

Найбільша кількість опенька зимового вирощується у Китаї. Згідно досліджень Y. Zhang, їстівні гриби там вирощують біля 25 мільйонів фермерів, а енокі посідає третє місце після гливи та шіїтаке за кількістю виробленої грибної сировини. Споживання і, відповідно, виробництво дереворуйнівних грибів постійно зростає: кількість гливи на місцевих ринках виросла в 1,36, шіітаке в 1,71, а фламуліни в 2,12 рази з 2007 до 2015 року [15]. Зазвичай, вирощуванням опенька займаються невеликі господарства, наприклад, в провінції Шандунь фермери виробляють 3666 кг цих грибів на добу [16].

Мета дослідження. 3 метою визначення основних факторів ефективного культивування опенька зимового в місцевих умовах та скринінгу перспективних штамів, придатних до впровадження у промислову культуру, практичні досліди проходили під керівництвом співробітників відділу мікології Інституту ботаніки ім. М. Г. Холодного в лабораторії Таврійського державного агротехнологічного університету ім. Дмитра Моторного та на підприємствах з 2012 по 2019 рік.

Матеріали i методи дослідження. Для ефективного впровадження в культуру необхідно було отримати дані щодо морфологічних особливостей та біологічного потенціалу штамів, наявних у колекції. За попередніми лабораторними дослідами щодо вегетативних характеристик, були відібрані 10 штамів Flammulina velutipes 3 Колекції культур шапинкових грибів IBK Інституту ботаніки ім. М. Г. Холодного НАН України [17]. До групи 1 віднесли 6 «промислових» штамів, що вже проходили апробацію в інших країнах: 1974, 1994 (Японія), 1860 (Ізраїль), 2038, 2039 (США ), 2337 (Україна). Штами групи 2 «природні» були виділені з плодових тіл, знайдених на деревині різних листвяних порід у природних умовах: 1880, 1884, 1885. До цієї групи додали штам FV, який було виділено 3 плодового тіла, знайденого на білій акації (Robinia pseudoacacia) в лісосмузі поблизу м. Дніпро. Культури зберігалися в пробірках 3 живильним середовищем наступного складу: солодовий екстракт сухий 30 г, агар-агар - 20г, вода до 1 літра, палички 3 берези $(2 \times 140 \times 5 \mathrm{Mm})$. Пробірки стерилізували за температури $120 \pm 2{ }^{\circ} \mathrm{C} \quad(1,2$ атм $)$ протягом 40 хвилин. Через 8-10 днів інкубації за температури $26 \pm 1{ }^{\circ} \mathrm{C}$, коли міцелій покривав 95-100\% площі косого зрізу, зберігали в холодильнику за температури $3 \pm 1{ }^{\circ} \mathrm{C}$. Перед виготовленням зернового міцелію культурами інокулювали чашки Петрі 3 сусло-агаром, інкубували за температури $24 \pm 1{ }^{\circ} \mathrm{C}$ протягом 9士 1 діб [18]. Повністю колонізоване культурою штаму 
Бандура І. І., Бісько Н. А., Кулик А. С., Цизь О. М., Чаусов С. В., Василенко О. Ю., Гончаров С. М.

середовище додавали до стерильної води (250 мл) та подрібнювали за допомогою спеціального блендера 3 дотриманням мікробіологічної чистоти. Отриману суспензію використовували для інокуляції зернової суміші у кількості 75 мл на один пакет.

Посівний зерновий міцелій для лабораторних і промислових випробувань виготовляли в умовах ТОВ НВП «Грибний лікар» (м. Мелітополь) відповідно до вимог ТУ У 01.3-41163069-001:2017. Використовували зернову суміш 3 зерна проса, пшениці, ріпаку та насіння льону у співвідношенні 70/25/4/1 на суху масу. Ріпак напередодні заливали холодною водою в співвідношенні 1/3. Залишали для набухання на 8-9 годин. У киплячу воду об'ємом $150 \pm 10$ л (котел харчовий КПЕ 350) засипали просо, варили $28 \pm 3$ хвилин, додавали пшеницю та продовжували варити зернову суміш ще $18 \pm 3$ хвилин. Настоювали у воді $18 \pm 2$ хвилин і зливали надлишок води. Готову суміш вивантажували в ємності для охолодження. Додавали вологий ріпак, сухе насіння льону, крейду (1кг на 100 кг зволоженою зернової суміші, ретельно перемішували i охолоджували до температури $35 \pm$ $5{ }^{\circ} \mathrm{C}$ за допомогою примусової повітряної вентиляції. Готову суміш засипали в поліпропіленові пакети компанії $\mathrm{SacO}_{2}$ (Бельгія) масою $5100 \pm$ 50 г. Стерилізацію проводили в режимі температури $125 \pm 2{ }^{\circ} \mathrm{C}$ протягом $190 \pm 10$ хв.

Пакети зі стерильною зерновою сумішшю вивантажували для охолодження в умовах «чистої» зони. Інокуляцію пакетів культурою відповідних штамів проводили в асептичних умовах (HЕРА 14) i ретельно перемішували. Інкубацію проводили за температури $24 \pm 1{ }^{\circ} \mathrm{C}$ в умовах чистої зони протягом 10 діб, після чого готовий зерновий міцелій зберігали в холодильнику за температури $1 \pm 1{ }^{\circ} \mathrm{C}$

\section{Виготовлення}

субстратів.

Субстрати для вирощування готували двома методами: 1) пастеризація, 2) стерилізація.

Пастеризацію варіантів субстратів проводили за наступним алгоритмом:

А) Складали варіанти формул субстратів відповідно до даних попередніх дослідників, але 3 урахуванням особливостей місцевої сировини [19-21]. Було зроблено 8 варіантів:

1) контрольний за даними іранських дослідників, які отримали $265 \%$ біологічної ефективності опенька зимового 3 субстрату наступного складу: тирса 400 г, солома подрібнена 400 г, висівки пшеничні 180 г, крейда 20г на один кг сухої суміші [20];

2) солома (400 г), лушпиння (590 г), крейда (10 г);

3) лушпиння (990 г), крейда (10 г); 
Агрономія

Бандура І. І., Бісько Н. А., Кулик А. С., Цизь О. М., Чаусов С. В., Василенко О. Ю., Гончаров С. М.

4) тирса (500 г), лушпиння соняшнику (490 г), крейда (10 г);

5) тирса $(800$ г), пшеничні висівки $(100 \quad$ г), подрібнені кукурудзяні початки (90 г), крейда (10 г);

6) лушпиння (500 г), гранули 3 лушпиння (300 г), кукурудзяна мука (190 г), крейда (10 г);

7) лушпиння (500 г), гранули 3 лушпиння (300 г), зерно ріпаку (190 г), крейда (10 г);

8) лушпиння (400 г), гранули 3 лушпиння (300 г), кукурудзяна крупа (200 г), зерно ріпаку (90 г), крейда (10 г).

Б) Зволоження отриманих сумішей проводили у співвідношенні 600 мл води (температура $18-20{ }^{\circ} \mathrm{C}$ ) на 400 г суміші, для отримання показника 60-67\% відносної вологості у підготовленій сировині [22].

В) Підготовлений субстрат засипали у пастеризаційну ємність насипом та проводили температурну обробку за наступним температурним графіком:

- 70-72 ${ }^{\circ} \mathrm{C}$ протягом $7 \pm 1$ години;

- $45-48^{\circ} \mathrm{C} \quad 3$ підтриманням рециркуляції внутрішнього повітря 8 годин;

- зниження 345 до $30{ }^{\circ} \mathrm{C}$ протягом 1-2 годин.

Г) Пастеризований субстрат в асептичних умовах інокулювали зерновим міцелієм в кількості 40 г на 1000 г субстрату та формували блоки субстратів масою 10 кг (середня

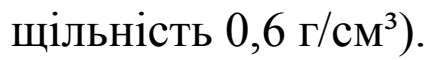

Д) Блоки інкубували за температури не вище $22{ }^{\circ} \mathrm{C}$ в центрі. Середня температура навколишнього повітря камери складала не більше 18 ${ }^{\circ} \mathrm{C}$.

Е) Процес плодоношення проводили за різної температури від 5 до $25^{\circ} \mathrm{C}$.

Стерилізацію субстратів за визначеною у досліді 3 пастеризованими субстратами формули 8 проводили за температури 121-125 ${ }^{\circ} \mathrm{C}$ протягом 120 хв. Для фасування субстратів використовували поліпропіленові пакети виробництва компанії «Технофільтр-Україна» двох типорозмірів 3 чотирма повітряно проникними фільтрами.

Готували два варіанти маси субстрату 3 i 1,5 кг. Стерилізовані пакети охолоджували в асептичних умовах (очищення повітря 99,95 \%) та інокулювали зерновим міцелієм в ламінарному потоці повітря (ступінь очищення 99,99 \%). Маса міцелію для інокуляції складала 30 г на 1000 г субстрату. Пакети запаювали, субстрат ретельно перемішували 3 міцелієм та ущільнювали легким натисканням до показника $0,7 \pm 1$ г/ $\mathrm{cm}^{3}$. Пакети встановлювали на стелажі таким чином, щоб над субстратом було достатньо повітря. Інкубацію проводили за температури $24 \pm 1{ }^{\circ} \mathrm{C} 3$ відносною вологістю повітря 60-65 \%.

Плодоношення проводили за температури $14 \pm 1^{\circ} \mathrm{C}$, з інтенсивністю освітлення 150 люкс протягом 8-10 
Бандура І. І., Бісько Н. А., Кулик А. С., Цизь О. М., Чаусов С. В., Василенко О. Ю., Гончаров С. М.

годин на добу. Відносна вологість повітря під час формування плодових тіл складала $87 \pm 2 \%$.

Визначали масу виготовленого блоку (пакету), масу пакету після стерилізації, інкубації, масу блоків (пакетів) після плодоношення для визначення динаміки втрати вологи. Вологість субстратів визначали гравіметричним методом за температури $101 \pm 1^{\circ} \mathrm{C}$. Активну кислотність фіксували у виготовлених субстратах за допомогою $\mathrm{pH}$ метру 150МИ за вимогами ГОСТ 26180-84. Зольність субстрату визначати методом сухого озолення згідно з ГОСТ 10847-74. Вміст загального азоту визначали хлорамінним методом за Починком [23]. Відношення $\mathrm{C} / \mathrm{N}$ визначали за формулою $\mathrm{C} / \mathrm{N}=0,52(100-\mathrm{a}) / \mathrm{N}$, де $\mathrm{a}-$ показник зольності, \%; 0,52 коефіцієнт вмісту вуглеводів, корегований 3 урахуваннях біохімічних особливостей сировини; $N$ - вміст загального азоту у субстраті [24].

Технологічний

цикл виробництва оцінювали за показниками тривалості інкубації (TI) та тривалості морфогенезу (ТМ). Термін інкубації вираховувався для кожного окремого блоку субстрату від дати інокуляції до дати появи примордіїв у стадії так званої «ікри». Треба зазначити, що для ініціації плодоношення 3 моменту появи на поверхні субстрату краплин ексудативної рідини, верхню частину пакету відкривали, але залишали плівку висотою 15-20 см. Відкриту поверхню звільняли від повітряного міцелію легкими торканнями [25]. Зміни мікрокліматичних параметрів та освітлення проводили згідно 3 рекомендаціями

попередніх дослідників [26].

Тривалість морфогенезу визначали від дати появи перших примордіїв до дати збирання урожаю плодових тіл. Біологічну ефективність (БЕ) розраховували відношенням маси плодових тіл першої хвилі плодоношення до маси сухих речовин субстрату.

Для скринінгу штамів, придатних до впровадження в промислову культуру, використовували блоки субстратів, виготовлені за методом пастеризації, масою 5000 г. Норма внесення посівного міцелію 4\% (200 г на блок). Після розташування на полицях робили отвори діаметром 60 мм у кількості 12 штук рівномірно по поверхні сформованого блоку.

Вплив маси та формули субстрату на ефективність трьох обраних після скринінгу штамів: 2038 (білий колір), 2039 (світло-жовтий зі світлою ніжкою) та 2337 (темножовтий $з$ темною ніжкою), вивчали на субстратах, виготовлених методом стерилізації. Вибірка складала від 20 до 50 блоків субстратів по кожному 3 варіантів в залежності від досліду. Повторність дослідів трикратна. 
Бандура І. І., Бісько Н. А., Кулик А. С., Цизь О. М., Чаусов С. В., Василенко О. Ю., Гончаров С. М.

Статистичну обробку дослідних даних проводили за допомогою пакету Microsoft Office Excel 2016 (ліцензія № HXV8M-8YJJ4-BCGR3MRYX-8747Q), та програмноінформаційного комплексу "Agrostat New" (2013) [27].

\section{Результати}

дослідження.

Одним 3 найважливіших факторів для введення штаму у промислове виробництво $€$ його зовнішня привабливість для споживача. В країнах Азії перевагу віддають грибам світлого кольору, тоді як в Україні насиченість кольору шапинки вважається необхідною складовою успішного продажу. Місцеві виробники стверджують, що покупці

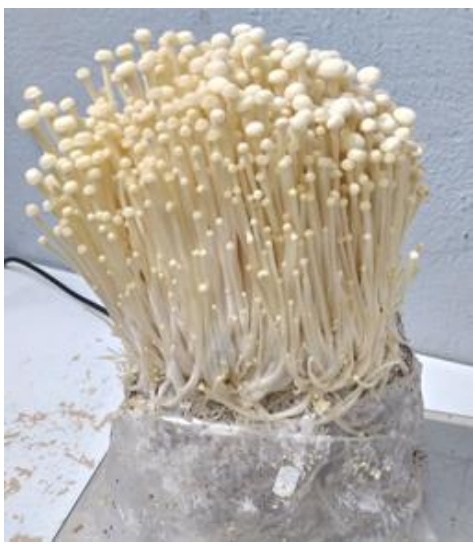

a

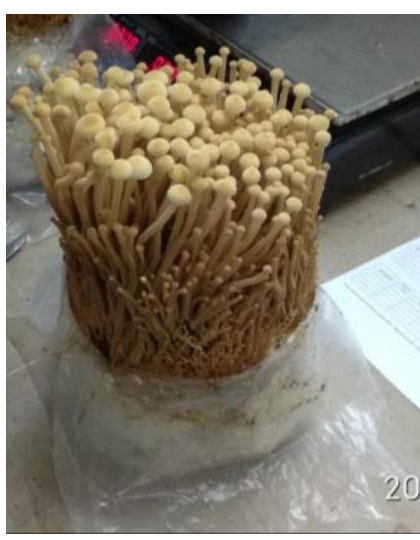

6 звертають увагу на колір ніжки, який у деяких штамів опенька зимового 3 настанням біологічної стиглості стає насичено-темним. Така біологічна особливість відштовхує потенціальних клієнтів. У сучасній науковій літературі ми не знайшли даних про біохімічні відмінності штамів, які мають різний колір, але основною вимогою скринінгу став пошук штамів, у яких зазначений фактор є відсутнім або має менший прояв. За результатами досліду було відібрано три штами 3 необхідними морфологічними ознаками та високим виробничим потенціалом: 2038, 2039 та 2337 (рис. 2, табл. 1).

Рис. 2. Штами Flammulina velutipes, 2039 (б) та 2337 (в)

1. Результати скринінгу штамів Flammulina velutipes (колекція IBK)

\begin{tabular}{|c|c|c|c|c|c|c|c|}
\hline № & Штам & ТІ, доба & $\begin{array}{c}\text { ТМ, } \\
\text { доба }\end{array}$ & БЕ,\% & $\begin{array}{c}\text { Колір } \\
\text { шапинки }\end{array}$ & Колір ніжки & БН \\
\hline 1 & 1860 & 38 & 19 & 29,7 & с-жовтий & т-коричневий & - \\
\hline 2 & 1974 & 45 & 12 & 39,8 & я-жовтий & т-коричневий & - \\
\hline 3 & 1994 & 45 & 17 & 25,7 & білий & білий & - \\
\hline 4 & $\mathbf{2 0 3 8}$ & 35 & $10^{\text {a }}$ & 45,4 & білий & білий & - \\
\hline 5 & $\mathbf{2 0 3 9}$ & 30 & $\mathbf{8}^{\mathbf{a}}$ & $51,3^{\text {a }}$ & с-жовтий & жовтий & - \\
\hline 6 & $\mathbf{2 3 3 7}$ & $\mathbf{2 6}$ & 12 & $\mathbf{5 2 , 6}^{\mathbf{a}}$ & с-жовтий & т-коричневий & - \\
\hline 7 & 1880 & 37 & 18 & 32,8 & жовтий & т-коричневий & + \\
\hline 8 & 1884 & 35 & 11 & 34,6 & с-жовтий & т-коричневий & - \\
\hline 9 & 1885 & 38 & 19 & 39,8 & с-жовтий & т-коричневий & - \\
\hline
\end{tabular}


Бандура І. І., Бісько Н. А., Кулик А. С., Цизь О. М., Чаусов С. В., Василенко О. Ю., Гончаров С. М.

\begin{tabular}{|c|c|c|c|c|c|c|}
10 & $\mathrm{FV}$ & 30 & $10^{\mathrm{a}}$ & 47,4 & бежевий & т-коричневий \\
\hline
\end{tabular}
яскравий; БН - «бактеріальна нестійкість», або відсутність у штаму стійкості до бактеріозу $[28,29]$; ТІ - термін інкубації, ТМ - термін морфогенезу, БЕ - біологічна ефективність.

Біологічна ефективність $є$ культуру. Визначення впливу складу найважливішим фактором 8 композицій субстратів на цей економічної доцільності впровадження штамів в промислову показник потребувало детального аналізу їхніх формул (табл. 2).

\section{2. Фізико-хімічний склад композицій субстратів у досліді}

\begin{tabular}{|l|c|c|c|c|c|}
\hline \multicolumn{1}{|c|}{ Варіант } & $\mathrm{C} / \mathrm{N}$ & Зола, $\%$ & $\begin{array}{c}\mathrm{N} \\
\text { загальний, } \%\end{array}$ & Вологість, $\%$ & $\mathrm{pH}$ \\
\hline 1 (контроль) & 63 & 3,67 & 0,79 & 66,9 & 5,9 \\
\hline 2 & 88 & 3,48 & 0,57 & 67,1 & 5,8 \\
\hline 3 & 83 & 2,25 & 0,61 & 66,7 & 6,4 \\
\hline 4 & 58 & 3,8 & 0,87 & 65,2 & 6,1 \\
\hline 5 & 51 & 4,7 & 0,97 & 63,8 & 5,6 \\
\hline 6 & 50 & 3,8 & 1 & 68,3 & 5,8 \\
\hline 7 & 41 & 5,4 & 1,2 & 69 & 6,1 \\
\hline 8 & 31 & 9,3 & 1,53 & 71,9 & 6 \\
\hline
\end{tabular}

На думку багатьох дослідників збалансованість вмісту карбону та нітрогену $\epsilon$ найбільш вагомим фактором для отримання високих урожаїв. Зокрема, оптимальним для ефективного фламуліни культивування співвідношення цих елементів на рівні 30/1 [11]. Лише композиція 8, у складі якої 70 \% складали відходи виробництва соняшнику, $20 \%$ цільнозернової кукурудзи та $9 \%$ зерна ріпаку відповідала цьому показнику. За іншими критеріями використані формули субстратів знаходилися в межах оптимальних показників субстратів, які опубліковано в науковій літературі.

За попередніми даними при вирощуванні енокі важливою складовою успіху є висока щільність субстратів, тому використання у їх формулах соломи місцевих сортів потребує додаткових технологічних заходів. Солома має бути подрібненою до часточок розміром 23 мм, що з оглядом на високий вміст силікатів у іiі структурі, $\epsilon$ енерговитратною операцією.

$\mathrm{У}$ роботах дослідників різних країн зазначалась необхідність підтримання показника вологості субстрату на рівні $60-70 \%$ [19,26]. Треба зазначити, що використання гранул з лушпиння соняшнику або соломи надає можливість легко контролювати цей показник. 3 урахуванням початкової вологості гранул на рівні $7 \%$, додавання розрахункової кількості води 3 
Бандура І. І., Бісько Н. А., Кулик А. С., Цизь О. М., Чаусов С. В., Василенко О. Ю., Гончаров С. М.

температурою $36-40{ }^{\circ} \mathrm{C}$ давало змогу отримати рівномірно зволожену фракцію субстрату протягом кількох хвилин.

Отже, відходи соняшника, що $\epsilon$ доступними рослинними залишками на більшості території України, мають найбільші перспективи щодо використання у вітчизняному виробництві фламуліни [30] .

Це ствердження обгрунтовано статистичним аналізом показників біологічної ефективності

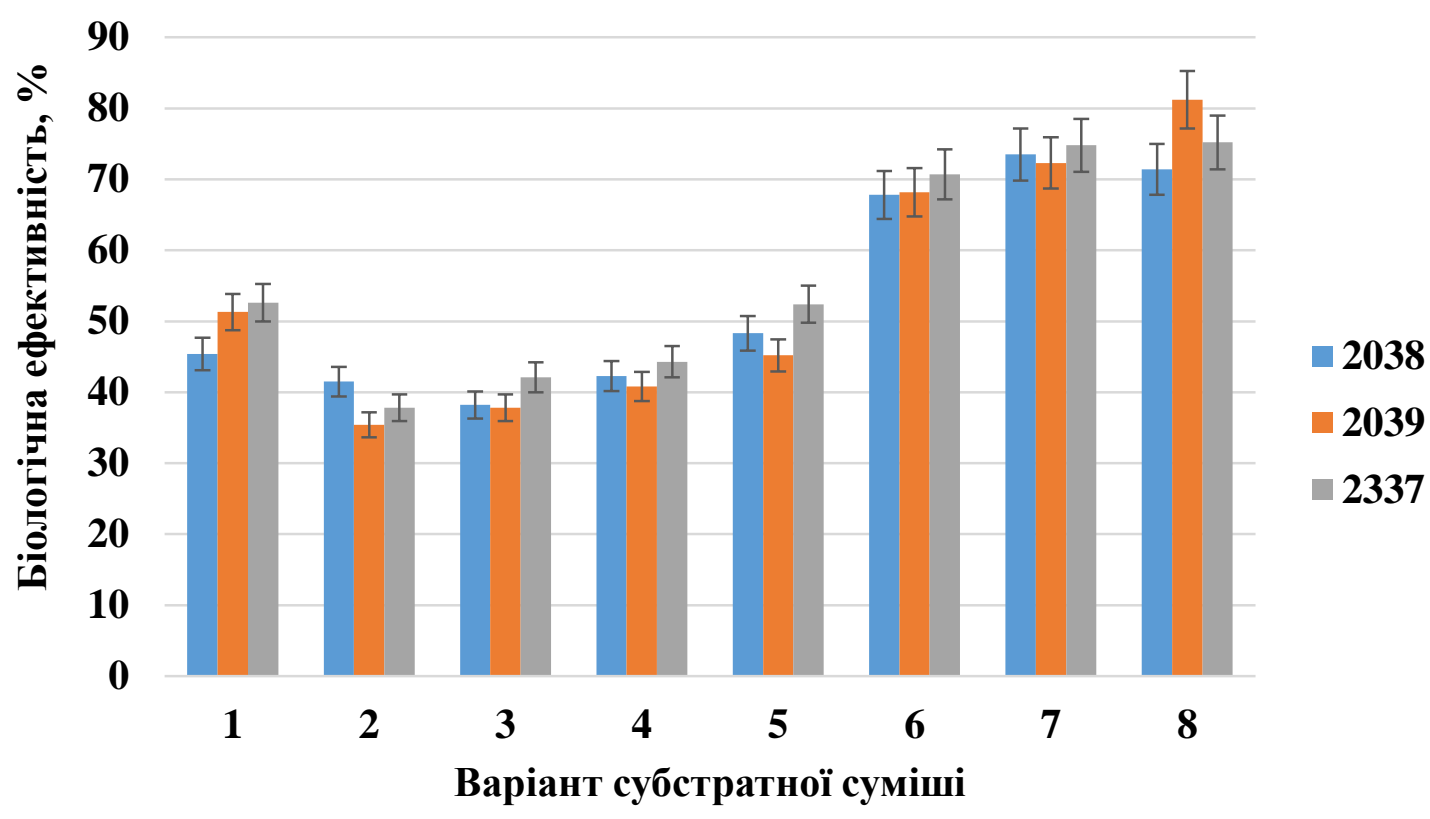

Рис. 3. Біологічна ефективність штамів Flammulina velutipes 2337, 2039, 2038 на варіантах суб̆стратів 1-8

На субстратах формул 6,7 та 8 ми отримали достовірно вищі результати. Наприклад, штам 2039 на субстраті №8 мав $81,2 \%$ БЕ, що в 2,3 рази вище, ніж на субстратах формули 2. Відповідно до результатів двохфакторного дисперсійного аналізу доведено доцільність використання формул 6-8, що містили 30 \% гранул з лушпиння. 3 оглядом на інші показники складу субстратів, тільки цей фактор виявився найбільш впливовим.

Наприклад, елементне співвідношення $\mathrm{C} / \mathrm{N}$ в формулах 5 і 6 практично не відрізнялося, але інгредієнти мали різну природу полісахаридного складу. Тому, для наукового

обгрунтування оптимальної формули субстрату для вирощування грибів треба враховувати не тільки загальноприйняті біохімічні критерії, а приділяти увагу молекулярній будові сировини. Вважаємо, що це питання потребує подальшого вивчення.

Термін інкубації $\epsilon$ основною характеристикою вегетативної стадії розвитку культури. На дослідних формулах ми мали повну колонізацію на рівні 38-42 діб, що відповідає 
Бандура І. І., Бісько Н. А., Кулик А. С., Цизь О. М., Чаусов С. В., Василенко О. Ю., Гончаров С. М.

опублікованим фактам, але треба зазначити, що швидкість засвоєння субстратів була достовірно вищою на субстратах, де співвідношення $\mathrm{C} / \mathrm{N}$ було на рівні 31-63/1 (рис. 4, табл.2). Фактор біологічних властивостей культури виявився несуттєвим, за виключенням росту штаму 2038 на контрольному варіанті субстрату, де поява примордій відбувалася на 5 діб пізніше порівняно з двома іншими. Треба зазначити, що й в 2,3 та 8 варіантах досліду цей штам також відставав від інших за цим показником.

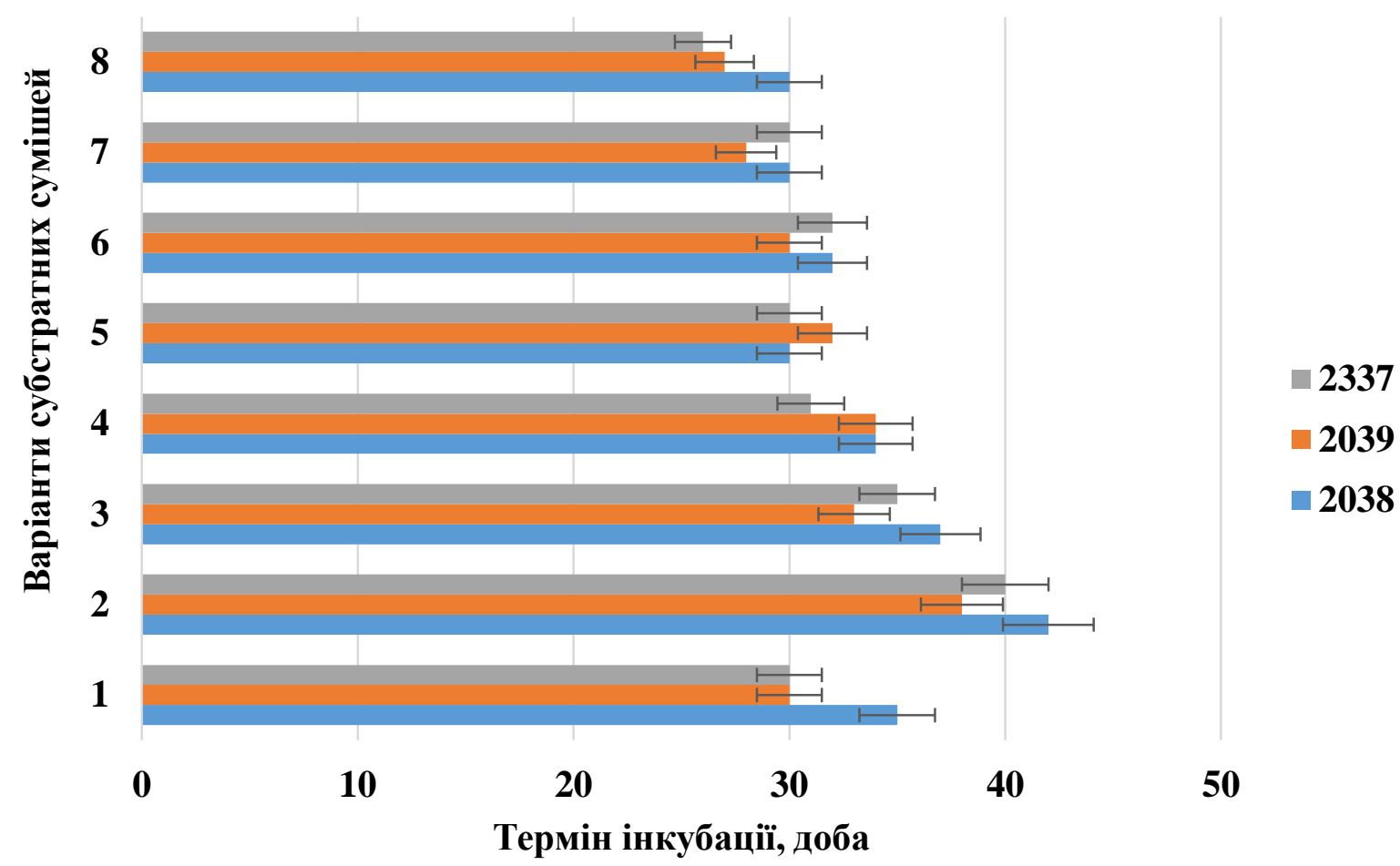

Рис. 4. Тривалість інкубації штамів Flammulina velutipes 2337, 2039, 2038 на варіантах субстратів 1-8

Загальний показник швидкості вегетативного розвитку $3 \mathrm{a}$ порівнянням середніх (U-тест) виявився найкращим у штаму 2337.

Треба додати, що перехід до генеративної стадії був найкоротшим на субстраті формули 8 для штамів 2337 та 2039 з терміном 27 і 28 діб відповідно, тоді як на субстраті 2 зафіксовано появу примордіїв лише на 39-42 добу.

Отже, у загальному підсумку, формула субстрату №8 виявилася найбільш ефективною для культивування досліджених штамів.

Важливою технологічною ознакою $\epsilon$ тривалість морфогенезу плодових тіл, за якою визначають закінчення циклу культури. За цим показником статистично доведених відмінностей між штамами не виявлено, термін морфогенезу не залежав також від формули 
Бандура І. І., Бісько Н. А., Кулик А. С., Цизь О. М., Чаусов С. В., Василенко О. Ю., Гончаров С. М.

композицій субстратів (рис.5).

Загальна тривалість формування плодових тіл складала від 7 до 13 діб. За порівнянням середніх, цей термін був нижчим для штаму 2039.
Отже, загальний цикл вирощування цього штаму був найкоротшим, порівняно 3 іншими, i складав у середньому 34 доби на варіанті субстрату 8 .

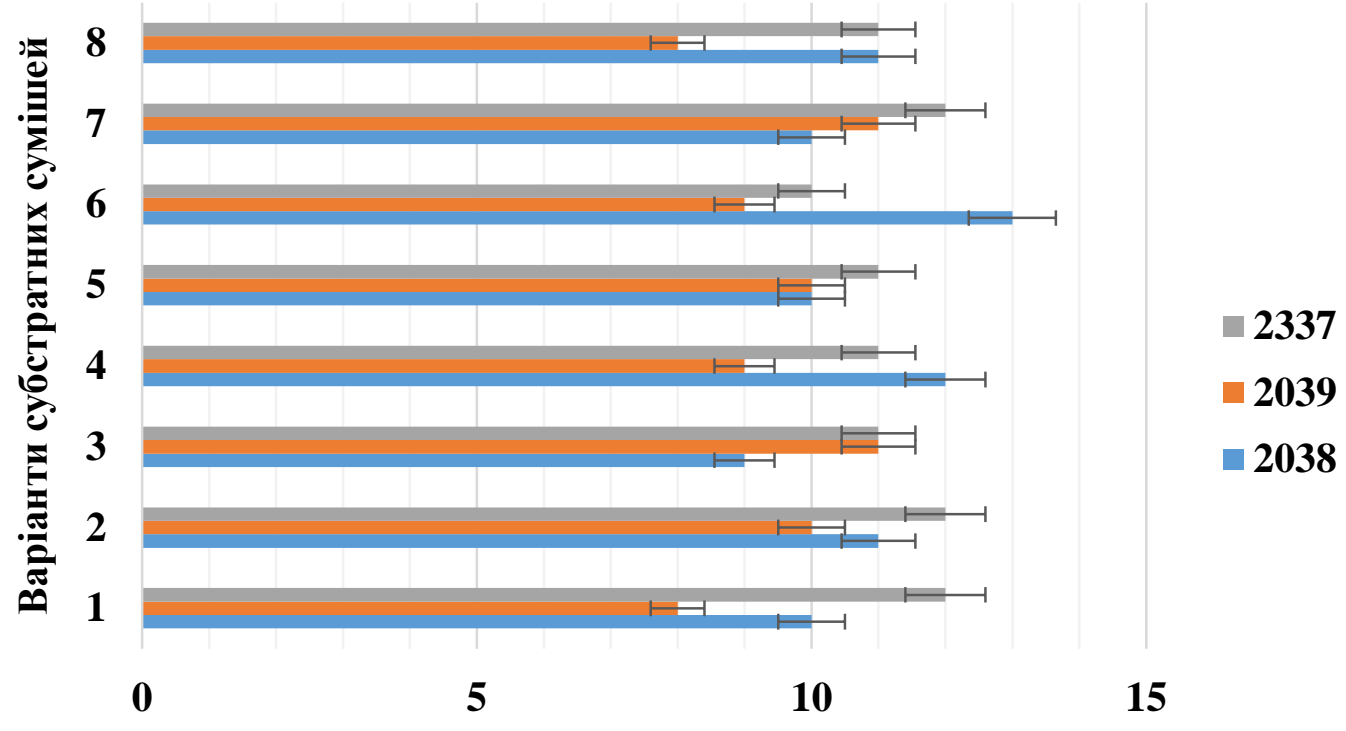

Термін морфогенезу, доба

Рис. 5. Тривалість розвитку плодових тіл штамів Flammulina velutipes 2337, 2039, 2038 на варіантах субстратів 1-8.

Одним $\quad 3 \quad$ важливих

технологічних

вирощування

$\epsilon$ формування

субстратних брикетів. Визначена у попередніх дослідах необхідність стерилізації субстратів спонукала до пошуку оптимальних розмірів пакетів, які б забезпечували ефективне знезараження в умовах промислових автоклавів.
Для перевірки впливу маси блоку субстрату на біологічну ефективність штаму 2039 проводили випробовування на пакетах 3 субстратом формули 8 масою 3000 та 1500 грамів. Визначено, що маса субстрату суттєво не впливає на загальний технологічний цикл, але обумовлює достовірне $(p<0,01)$ збільшення показника біологічної ефективності (табл. 3, рис. 6).

3. Технічні показники штаму Flammulina velutipes 2039 на блоках субстрату формули 8 різної маси

\begin{tabular}{|l|c|c|}
\hline \multirow{2}{*}{\multicolumn{1}{|c|}{ Показник }} & \multicolumn{2}{c|}{ Варіанти пакетів за масою, $\Gamma(n=50)$} \\
\cline { 2 - 3 } & $1535 \pm 51$ & $3078 \pm 39$ \\
\hline Термін інкубації, доба & $28 \pm 3$ & $32 \pm 2$ \\
\hline Термін морфогенезу, доба & $11 \pm 3$ & $12 \pm 3$ \\
\hline Біологічна ефективність, \% & $121,2 \pm 17,3$ & $75,8 \pm 9,4$ \\
\hline Втрати маси субстрату під час інкубації, \% & $2,24 \pm 0,2$ & $2,27 \pm 0,1$ \\
\hline Втрати маси субстрату після першої хвилі, \% & $24,3 \pm 5,3$ & $19,2 \pm 4,3$ \\
\hline
\end{tabular}




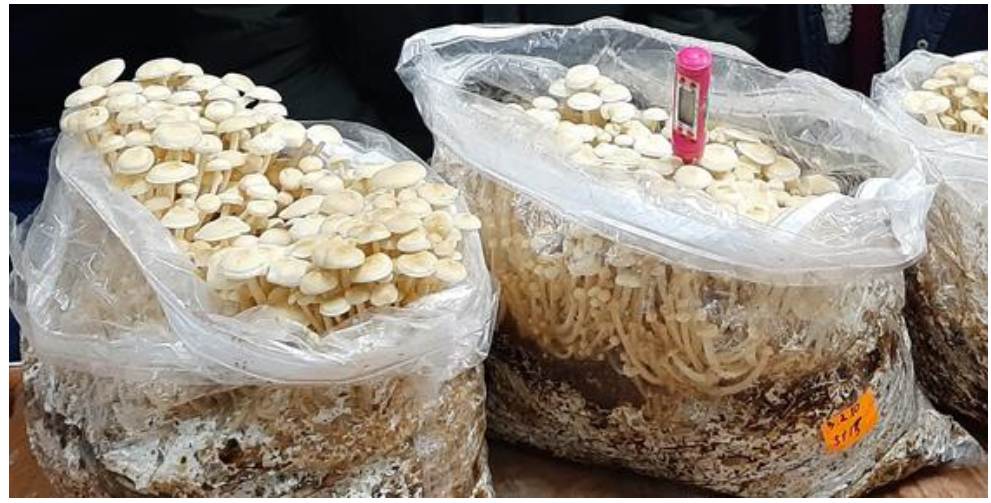

a

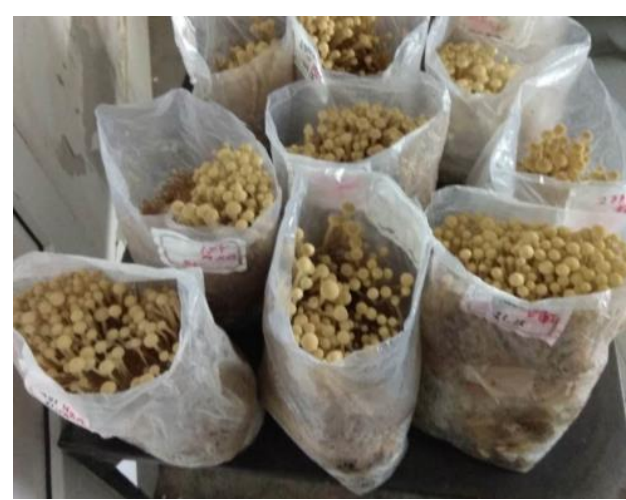

б

Рис. 6. Плодоношення штаму Flammulina velutipes 2039 за використання блоків субстрату формули 8 різної маси: а) 3000 г; б) 1500 г

За рахунок використання поліпропіленових пакетів 3 повітряними фільтрами під час інкубації загальний показник втрати маси складав біля 2\%, що мало пряму кореляцію 3 загальною втратою вологи у субстраті. Після відкриття пакетів для формування плодових тіл та подальших технологічних операцій, пов'язаних 3 отриманням урожаю, втрати маси субстрату на пакетах різної маси відрізнялася, хоча суттєвої різниці диференційним аналізом не визначено.

Отже, за результатами досліду доведено що біологічна ефективність штаму 2039 на блоках субстрату формули 8 масою 1500 г була в 1,6 рази вищою порівняно 3 варіантом блоків масою 3000 г. 3 оглядом на отримані дані зрозуміло, що питання пошуку оптимальної маси пакету 3 урахуванням собівартості та зменшення технологічних операцій потребує подальшого вивчення.

Висновки i перспективи. Проведено скринінг 10 штамів опенька зимового 3 метою визначення морфологічних та технічних ознак, які дадуть змогу впровадити ці штами в умови індустріального грибівництва. За отриманими даними штами 2038 (біла paca), 2039 та 2337 (жовта раса) 3 успіхом пройшли інтродукцію в умови місцевих господарств СФГ «Жовтневе» та ФОП Гончаров С.М.

Визначено, що дані штами мали найвищі показники біологічної ефективності на субстратах формули: лушпиння $(400$ г), гранули 3 лушпиння (300 г), кукурудзяна крупа (200 г), зерно ріпаку (90 г), крейда (10 г).

Загальна

тривалість вегетативного розвитку та морфогенезу означених штамів на субстратах оптимальної формули суттєво не відрізнялась і складала 2832 та 8-11 діб відповідно. Отже, технологічний цикл отримання першої хвилі плодових тіл складав від 36 до 43 діб, що відповідає даним наукової літератури.

Виявлено, що біологічна ефективність штаму 2039 опенька зимового, вирощеного в субстратних 
Агрономія

Бандура І. І., Бісько Н. А., Кулик А. С., Цизь О. М., Чаусов С. В., Василенко О. Ю., Гончаров С. М.

пакетах масою 1500 г була вищою в 1,6 рази порівняно 3 варіантом 3 масою пакетів 3000 г. Пошук оптимальної маси пакетів для індустріального вирощування опенька зимового має бути обгрунтованим з оглядом на вартість поліпропіленових пакетів та збільшенням трудовитрат за умов виготовлення субстрату в пакетах меншої маси.

Адаптаційні характеристики обраних штамів за умов вирощування на місцевих сільськогосподарських відходах, зокрема морфологічні особливості, вплив мікрокліматичних умов, стійкість до захворювань потребують подальших досліджень. Особливу увагу треба приділити Refereces

1. Tang, C., Hoo, P. C. X., Tan, L. T. H., Pusparajah, P., Khan, T. M., Lee, L. H., Chan, K. G. (2016). Golden needle mushroom: a culinary medicine with evidenced-based biological activities and health promoting properties. Frontiers in pharmacology. vol. 7, 474. DOI: 10.3389/fphar.2016.00474.

2. Dowom, S. A., Rezaeian, S., Pourianfar, H. R. (2019). Agronomic and environmental factors affecting cultivation of the winter mushroom or Enokitake: achievements and prospects. Applied microbiology and biotechnology, vol. 103(6), pp. 2469-2481. DOI: 10.1007/s00253-01909652-y

3. Dudka, I.A., Bis'ko, N.A., Bilaj, V.T. (1992). Kul'tivirovanie s'edobnyh gribov [Cultivation of edible mushrooms]. Kiev, Urozhaj, 160 p. (In Russian).

4. Negruckij, S.F. (1993). Industrial cultivation of edible mushrooms. Sb. tezisov IV Soveshhanija, 5-6 oktjabrja 1993 g [Sat. abstracts of the Conference IV, October 5-6, 1993, Donetsk: Donetsk State University,]. Doneck: Doneckij gosudarstvennyj universitet,1993. 59 p. (In Russian). визначенню біохімічних показників перспективних для впровадження в індустріальну культуру штамів фламуліни, як джерела функціональних речовин, що позитивно впливають на здоров'я людей.

Автори вдячні керівництву компанії ТОВ НВП «ГРИБНИЙ ЛІКАР» (директор Севастьянович В. М.) за можливість виготовлення зразків посівного зернового міцелію та проведення дослідів в умовах промислового виробництва.

Автори зазначають, що надані матеріали публікуються вперше, фотографії та наведені дані $\epsilon$ результатом особистих досліджень i не шкодять інтересам інших осіб.

5. Buhalo, A.S., Bis'ko, N.A., Solomko, Je.F., Poyedinok, N. L., Mykchaylova O. (2004). Kul'tivirovanie s'edobnyh i lekarstvennyh gribov [Cultivation of edible and medicinal mushrooms]. Kiev: Chernobyl'interinform, 128 p. (In Russian).

6. Popovich, V. P., Koziko, N. O., Butkevich, T. A. Perspektivi vikoristannja likars'kogo griba Flammulina velutipes u medichnij ta farmacevtichnij praktici [Prospects for the use of the medicinal fungus Flammulina velutipes in medical and pharmaceutical practice]. Farmacevtichnij zhurnal. [Pharmaceutical Journal], 2015, no. 1, pp. 70-75. Available at: http://nbuv.gov.ua/UJRN/pharmazh_2015_1_1 1. (Accessed 27 March 2020).

7. Bisko, N. A., Lomberg, M. L., Mytropolska, N. Yu., Mykchaylova, O. B. (2016). The IBK mushroom culture collection [Kolekcija kul'tur shapynkovyh grybiv (IBK)]. Kyiv: M.G. Kholodny Institute of Botany, National Academy of Sciences of the Ukraine, Alterpres, 120 p. (In Russian).

8. Chen, G. T., Fu, Y. X., Yang, W. J., Hu, Q. H., Zhao, L. Y. Effects of polysaccharides from the base of Flammulina 
Бандура І. І., Бісько Н. А., Кулик А. С., Цизь О. М., Чаусов С. В., Василенко О. Ю., Гончаров С. М.

Velutipes stipe on growth of murine RAW264.7, B16F10 and L929 cells. International Journal of Biological Macromolecules. 2018, Feb;107(Pt B), pp. 2150-2156.

DOI:

10.1016/j.ijbiomac.2017.10.090.

9. Ko, J. L., Hsu, C. I., Lin, R. H., Kao,

C. L., Lin, J. Y. A new fungal immunomodulatory protein, FIP-fve isolated from the edible mushroom, Flammulina velutipes and its complete amino acid sequence. European Journal of Biochemistry, 1995, 228(2), pp. 244249. DOI:10.1111/j.1432-1033.1995.0244n.x

10. Yeh, M.-Y., Ko, W.-C., Lin, L.-Y. Hypolipidemic and Antioxidant Activity of Enoki Mushrooms (Flammulina velutipes). BioMed Res. Int., 2014, vol. 2014. DOI: 10.1155/2014/352385

11. Jayachandran, M., Xiao, J., Xu, B. A. Critical Review on Health Promoting Benefits of Edible Mushrooms through Gut Microbiota: 9. Int. J. Mol. Sci. Multidisciplinary Digital Publishing Institute, 2017, vol. 18, № 9, pp. 1934. DOI: 10.3390/ijms18091934

12. Bao, H.N.D., Ochiai, Y., Ohshima, T. Antioxidative activities of hydrophilic extracts prepared from the fruiting body and spent culture medium of Flammulina velutipes. Bioresour. Technol., 2010, vol. 101, № 15, pp. 6248-6255.

DOI:

10.1016/j.biortech.2010.03.026

13. Chang, S.T., Hayes, W.A. (2013). The Biology and Cultivation of Edible Mushrooms. Academic Press, 841 p.

14. Kern, V. D., Hock, B. Gravimorphogenesis and ultrastructure of the fungus Flammulina velutipes grown in space, on clinostats and under hyper-g conditions. Advances in Space Research, 1996, vol.17, issue 6-7, pp.183-186. DOI: 10.1016/0273-1177(95)00633-P

15. Zhang, Y., Geng, W., Shen, Y., Wang, Y., \& Dai, Y. C. Edible mushroom cultivation for food security and rural development in China: bio-innovation, technological dissemination and marketing. Sustainability, 2014, May, vol. 6, issue 5. pp. 2961-2973. DOI: 10.3390/su6052961

16. Li, M., Hu, J. Study on survival strategies of farmers engage in small-scale household cultivation of edible mushrooms: take Shandong Province as an example. Modern economy, 2014, vol. 5(12), pp. 1092-1100. DOI: 10.4236/me.2014.512100

17. Mihajlova, O. B.; Poedinok, N. L. Nauchnye osnovy sozdanija perspektivnyh biotehnologij kul'tivirovanija lekarstvennyh makromicetov Piptoporus Betulinus (Bull.) P. Karst. I Flammulina Velutipes (Curtis) Singer [Scientific basics of creating promising biotechnologies for the cultivation of medicinal macromycetes Piptoporus Betulinus (bull.) P. Karst. and Flammulina Velutipes (curtis) Singer]. Uspehi medicinskoj mikologii [Advances in Medical Mycology], 2014, vol. 12. pp. 242-243. (In Russian).

18. Bilaj, V.I. (1982). Metody jeksperimental'noj mikologii [Methods of experimental mycology]. Kiev: Naukova dumka, 553 p. (In Russian).

19. Harith, N., Abdullah, N., Sabaratnam, V. Cultivation of Flammulina velutipesmushroom using various agroresidues as a fruiting substrate. Pesquisa Agropecuária Brasileira, 2014, vol. 49(3), pp. 181-188. Available at: http://www.scielo.br/scielo.php?pid=S010004X2014000300181\&script=sci_arttext. (Accessed 27 March 2020).

20. Rezaeian, S., Pourianfar, H.R. A Comparative Study on Bioconversion of Different Agro Wastes by Wild and Cultivated Strains of Flammulina velutipes. Waste Biomass Valorization, 2017. vol. 8, № 8, pp. 2631-2642. Available

at: https://link.springer.com/article/10.1007/s1264 9-016-9698-7. (Accessed 27 March 2020).

21. Osińska-Jaroszuk, M. O. N. I. K. A., Jaszek, M., Sulej, J., Stefaniuk, D., Urbaniak, M., Siwulski, M., Janusz, G. Complex biochemical analysis of fruiting bodies from newly isolated Polish Flammulina velutipes strains. Polish J Microbiol, 2016, vol. 65, №3, pp. 295-305. Available at: https://pdfs.semanticscholar.org/f8bd/dd0392e c0ba97ea7dc22091661c5a6badad6.pdf.

(Accessed 27 March 2020).

22. Leifa F., Pandey, A., Soccol, C.R. Production of Flammulina velutipes on coffee husk and coffee spent-ground. Braz. Arch. Biol. Technol. Tecpar, 2001. vol. 44, № 2, pp. 205- 
Бандура І. І., Бісько Н. А., Кулик А. С., Цизь О. М., Чаусов С. В., Василенко О. Ю., Гончаров С. М.

$212 . \quad$ DOI: $\quad 10.1590 /$ S151689132001000200015

23. Pochinok, H.N. (1976). Metody biohimicheskogo analiza rastenij [Methods of biochemical analysis of plants]. Kiev: Izdatel'stvo "Naukova dumka," 336 p.

24. Tarariko, O.G., Baljuk, S.A., Kisil', V.I. (2005). Metodika agrohimichnogo obstezhennja teplichnih gruntiv i substrativ ta osoblivosti zastosuvannja dobriv [Methods of agrochemical examination of greenhouse soils and substrates and features of fertilizer application]. K.: DIA, 205 p.

25. Chen, Y., Xiaobin, L., Jing, L., Zhuliang, Y. (2005). Flammulina velutipes variety, and cultivation method thereof. Patent EU, no. CN105248285.

26. Xie, C., Gong, W., Yan, L., Zhu, Z., $\mathrm{Hu}, \mathrm{Z}$., Peng, Y. Biodegradation of ramie stalk by Flammulina velutipes: mushroom production and substrate utilization. AMB Express. 2017, vol. 7, № 1, pp. 171-171. Available at: https://ambexpress.springeropen.com/articles/10.1186/s 13 568-017-0480-4. (Accessed 27 March 2020).

27. Ushkarenko, V.O., Vozhegova, R.A., Goloborodko, S.P., Kokovikhin, S.V. (2013). Programno-informacijnyj kompleks „Agrostat
New" [«Agrostat New» software and information complex]. Kherson: Island.

28. Han, H. S., Jhune, C. S., Cheong, J. C., Oh, J. A., Kong, W. S., Cha, J. S., Lee, C. J. Occurrence of black rot of cultivated mushrooms (Flammulina velutipes) caused by Pseudomonas tolaasii in Korea. European journal of plant pathology, 2012, vol. 133, № 3, pp. 527-535. Available at: https://link.springer.com/article/10.1007/s1065 8-012-9941-4 (Accessed 27 March 2020).

29. Liu, Z. H., Sossah, F. L., Li, Y., Fu, Y. P. First Report of Ewingella americana Causing Bacterial Brown Rot Disease on Cultivated Needle Mushroom (Flammulina velutipes) in China. Plant Dis. Scientific Societies, 2018, vol. 102, № 12, pp. 26332633. Available at: https://apsjournals.apsnet.org/doi/full/10.1094/ PDIS-02-18-0351-PDN (Accessed 27 March 2020).

30. Wright, L., Boundy, B., Perlack, B., Davis, S., \& Saulsbury, B. (2006). Biomass Energy Data Book, Volume 1., University of Nebraska - Lincoln, 189 p. Available at: https://digitalcommons.unl.edu/cgi/viewconten t.cgi article $=\quad 1000 \&$ context $=$ usdoepub . (Accessed 27 March 2020).

\title{
TECHNOLOGICAL PRINCIPLES FOR THE INTRODUCTION OF WINTER MUSHROOM (FLAMMULINA VELUTIPES (CURTIS) SINGER) INTO THE INDUSTRIAL CULTURE
}

\author{
I. I. Bandura, N. A. Bisko, A. S. Kulik, O. M. Tsyz, S. V. Chausov, \\ O. Y. Vasylenko, S. M. Goncharov
}

Annotation. Flammulina velutipes - enokitake or shortly - "enoki", is one of the most widely cultivated mushrooms on the planet. The value of the fruit bodies of the "gold mushroom" is determined by their high functional properties, in particular, the presence of bio-active proteins FIP-fve (fungal immunomodulatory protein), and 
Бандура І. І., Бісько Н. А., Кулик А. С., Цизь О. М., Чаусов С. В., Василенко О. Ю., Гончаров С. М.

special polysaccharides. Consumers like its delicate texture and bright rich aroma. In Ukraine, this mushroom is successfully grown in small-scale production, but the technological foundations for introducing it into industrial culture have not been developed until current time. The aim of the work was to determine the effective technical operations of the Flammulina industrial production using local agricultural wastes.

Ten strains from the IBK mushroom culture collection were checked, the most effective strains 2038 (white race), 2039 and 2337 (yellow race) were selected. These strains have been grown in industrial conditions and their main technical characteristics were studied: biological efficiency and technological cycle to the time of first fruiting flush. The average time for the crop was obtained in 40 days from the inoculation date.

The 8 substrate compositions from agricultural wastes were tested and as a result of the study, the optimal ingredient of the substrate formula was found - granules from sunflower husk. The time of substrate preparation was shorter when we were using these raw materials and we were obtaining the necessary density in addition.

The effect of packages weighing to the biological efficiency index of strain 2039 was noticed. The crop was in 1,6 times more in batches of substrate weighing $1500 \mathrm{~g}$ if compared with $3000 \mathrm{~g}$ variant.

According to our research, the local environment condition and its influence on the micro-climate in the growing rooms and morphological characteristics of Flammulina velutipes productive strains, their resistance to diseases requires further study for the development of successful industrial production.

Keywords: "enokitake", "winter mushroom", Flammulina velutipes, screening, biological efficiency, technological cycle, substratum, biochemical compositions, functional substances, introduction. 